\title{
Image analysis of papaya seeds submitted to sarcotesta removal methods ${ }^{1}$
}

\author{
Rogério Luciano Severiano², Paloma Rayane Pinheiro ${ }^{3}$, \\ Francisco Guilhien Gomes Júnior ${ }^{4}$, Andréa Celina Ferreira Demartelaere ${ }^{5}$, Márcio Dias Pereira ${ }^{2}$
}

\section{ABSTRACT}

The germination of papaya seeds is slow and uneven, usually due to inhibitors present in the sarcotesta; however, some removal procedures may cause physical damage, negatively interfering in the physiological quality and field performance. This study aimed to evaluate the physical and physiological quality of papaya seeds submitted to methods of sarcotesta removal by image analysis. Papaya Formosa 'Tainung 01' seeds were submitted to the following methods of sarcotesta removal: fermentation + sieve, sand + sieve, sieve and blender + sieve. After the sarcotesta removal, the seeds were submitted to tests of germination, first germination count, germination speed and seedling length. For the image analysis, the seeds without sarcotesta were submitted to the X-ray test and to a computerized analysis of seedling images by the SVIS ${ }^{\circledR}$ software. The methods used were only promising for the sarcotesta removal, while the blender + sieve method obtained the highest physical and physiological seed quality, in addition to performing the best sarcotesta removal. However, the image analysis using the SVIS ${ }^{\circledR}$ software allowed to identify the high physical and physiological seed quality using the blender + sieve method, which promoted the highest efficiency in removing the sarcotesta.

KEYWORDS: Carica papaya; seed dormancy; seed physiological quality.

\section{INTRODUCTION}

The consumption of tropical fruits has increasead in the national and international markets, due to the recognition of their nutritional and therapeutic properties. Papaya (Carica papaya L.)

\section{RESUMO}

Análise de imagens de sementes de mamão submetidas a métodos de remoção da sarcotesta

Agerminação de sementes de mamão é lenta e desuniforme, normalmente em função de inibidores presentes na sarcotesta; no entanto, alguns procedimentos de retirada podem acarretar danos físicos, interferindo, de forma negativa, na qualidade fisiológica e no desempenho em campo. Objetivou-se avaliar a qualidade física e fisiológica de sementes de mamão, submetidas a métodos de remoção da sarcotesta, por meio de análise de imagens. Sementes de mamão Formosa 'Tainung 01' foram submetidas aos seguintes métodos de remoção da sarcotesta: fermentação + peneira, areia + peneira, peneira e liquidificador + peneira. Após a retirada da sarcotesta, as sementes foram submetidas a testes de geminação, primeira contagem de germinação, velocidade de germinação e comprimento de plântula. Para a análise de imagem, as sementes sem sarcotesta foram submetidas ao teste de raios X e à análise computadorizada de imagens de plântulas pelo software SVIS ${ }^{\circledR}$. Os métodos utilizados mostraram-se promissores somente para a retirada da sarcotesta, enquanto o método peneira + liquidificador, além da melhor retirada, obteve alta qualidade física e fisiológica das sementes. Entretanto, a utilização do software SVIS ${ }^{\circledR}$ permitiu identificar a alta qualidade física e fisiológica das sementes com a utilização do método liquidificador + peneira, que promoveu maior eficiência na remoção da sarcotesta.

PALAVRAS-CHAVE: Carica papaya; dormência de semente; qualidade fisiológica de semente.

stands out because it presents a high nutritional value, being rich in sugars, minerals and bioactive compounds such as carotenoids, vitamin $\mathrm{C}$ and polyphenols (Reis et al. 2015).

The vegetative propagation in commercial plantations is carried out through seedlings, because

1. Received: Jun. 27, 2018. Accepted: Oct. 04, 2018. Published: Dec. 17, 2018. DOI: 10.1590/1983-40632018v4853699.

2. Universidade Federal do Rio Grande do Norte, Macaíba, RN, Brasil.E-mail/ORCID: rogerioagron@livel.com/ 0000-0001-7532-0007, marcioagron@yahoo.com.br/0000-0001-9729-6503.

3. Universidade Federal do Ceará, Departamento de Fitotecnia, Fortaleza, CE, Brasil. E-mail/ORCID: palloma.ana@hotmail.com/0000-0002-0219-1483.

4. Universidade de São Paulo, Escola Superior de Agricultura “Luiz de Queiroz", Departamento de Produção Vegetal, Piracicaba, SP, Brasil.E-mail/ORCID: francisco1@usp.br/0000-0001-9620-6270.

5. Universidade Federal da Paraíba, Centro de Ciências Agrárias, Areia, PB, Brasil. E-mail/ORCID: andrea_celina@hotmail.com/0000-0003-0427-0916. 
they are treated in a more economical and practical way, requiring the use of high quality seeds (Dias et al. 2015). The germination of papaya seeds occurs slowly and unevenly (Cavalcante et al. 2014). These factors probably take place due to the presence of the sarcotesta, a mucilaginous envelope that surrounds the seed and possesses phenolic compounds which inhibit germination, providing the physiological dormancy (Melo \& Seleguini 2013).

The sarcotesta removal is indicated by several authors as a method for overcoming dormancy, to obtain a greater uniformity and germination percentage (Cavalcante et al. 2014, Melo et al. 2015). It can be done in different ways, such as seed washing in running water using sieves (Cavalcante et al. 2014), seed friction in sand, pulsation with water in a blender (Cavalcante et al. 2014), brush swab with plastic bristles (Melo \& Seleguini 2013), washing under running water (Tokuhisa et al. 2007) and other methods such as fermentation, use of acids, bases and minerals (Cavalcante et al. 2014). However, some of these procedures may cause physical damage to the seeds, negatively interfering with their physiological quality and field performance (Jesus 2014).

In quality control programs of papaya seeds carried out by companies, it is important to evaluate the efficiency of the sarcotesta removal in overcoming dormancy, as well as impacts caused by physical or chemical processes involved in removing the mucilage. In addition to the traditional tests used for evaluating and controlling seed quality, the X-ray analysis has been shown as an alternative, because of its speed, efficiency and practicality in evaluating internal morphology and damage detection (Gomes et al. 2014).

In addition to X-ray testing, tests that evaluate seed vigor have been carried out using the Seed Vigor Imaging System (SVIS ${ }^{\circledR}$ ) software (Sako et al. 2001), which has been increasingly effective (Oliveira et al. 2004) in crops such as Ricinus communis L. (Oliveira et al. 2004), Handroanthus albus Cham. Mattos and Handroanthus impetiginosus Mart. ex DC. (Kobori et al. 2012), Ocotea pulchella Nees \& Mart. and Persea pyrifolia Nees \& Mart. (Carvalho et al. 2009), Cecropia pachystachya Trécul. (Pupim et al. 2008), Cucurbita moschata Duchesne ex Poiret (Carvalho et al. 2009) and Peltophorum dubium Spreng. Taub. (Oliveira et al. 2003), among others. This type of analysis has been highlighted for both accuracy and speed, and for maintaining the seed physiological quality (Wendt et al. 2014).
Thus, his study aimed to evaluate the physical and physiological quality of papaya seeds submitted to methods of sarcotesta removal by image analysis.

\section{MATERIAL AND METHODS}

The study was conducted at the Escola Superior de Agricultura "Luiz de Queiroz", Universidade de São Paulo, in Piracicaba, São Paulo state, Brazil, from August to December 2017.

For the seed acquisition, 40 Formosa 'Tainung 01 ' papayas at the maturity stage 5 were obtained in the local market, presenting $75-100 \%$ of yellow skin (Berbert et al. 2008).

The seeds were removed from the fruit with a spoon and homogenized in a container, forming a single sample. After homogenization, the sample was weighed and then the following sarcotesta removal procedures were performed: 1) fermentation + sieve - the seed sample was submerged in water, in a $500 \mathrm{~mL}$ beaker, for 3 days, until it was $1 \mathrm{~cm}$ above the seeds (Silva et al. 2015). The seeds were subsequently washed in running water, with a sieve, until the complete removal of the sarcotesta; 2) sand + sieve the seeds were placed in a container, mixed with an amount of sand equivalent to twice their volume and rubbed with hands. The entire contents of the vessel were then placed in a steel mesh screen containing a perforation smaller than the seed size, to promote its separation from sand, under a tap with running water; 3) sieve - the seeds were placed in a sieve with steel mesh with perforation smaller than their size, being pressed against it using the hands, until the sarcotesta ruptured. During this operation, the sieve was under tap with running water to facilitate the separation; 4) blender + sieve - the seeds were mixed with an amount of water equivalent to three times their volume and placed in a blender. The blender blades were initially protected with crepe tape, in order to reduce the direct impact of the cutting blades on the seeds. The process was carried out intermittently, the button was pressed for 2 seconds and then the device was turned off, and this process was repeated 10 times. After the procedure, the seeds were washed in running water, in a steel sieve, to remove the remaining sarcotesta.

After the treatments, the seeds were dried in a single layer on two sheets of paper towel, in a natural laboratory environment $\left(25^{\circ} \mathrm{C}\right.$ and relative humidity of $38 \%$ ), for $24 \mathrm{~h}$. 
After drying, the seeds submitted to each procedure had their water content determined according to Brasil (2009), and the following traditional tests were performed for quality evaluation, in order to determine their physiological characterization:

- Germination: seeds were distributed in 4 replicates of 50 seeds, at a temperature of $20-30^{\circ} \mathrm{C}$, with an alternating photoperiod of $12 \mathrm{~h}$ of light and $12 \mathrm{~h}$ of darkness, on paper rolls moistened with distilled water (2.5 times the weight of the dry substrate) and packed in plastic bags. Then, the number of normal seedlings (Brasil 2009) was determined. The final count was at 30 days, when the percentage of normal seedlings was determined;

- First germination count: conducted together with the germination test, with normal seedlings being evaluated at 14 days after the test installation;

- Germination speed: determined according to the formula proposed by Maguire (1962);

- Germination rate index: generated from the daily germination values, starting at the establishment of the germination test until its conclusion;

- Seedling length: seeds were distributed in 4 replicates of 25 seeds, in two rows, on a line drawn on the upper third of the germitest paper moistened with 2.5 times the weight of the paper (Krzyzanowski et al. 1999), under the same conditions described for the germination test. The evaluation was carried out using a ruler graduated in millimeters at 30 days after the test, under the same conditions as the germination test, and the results were expressed in centimeters;

- Shoot length and primary root length: the evaluation of shoot length (hypocotyl) and primary root length were performed in conjunction with the seedling length test. The evaluation was carried out using a ruler graduated in millimeters at 30 days after the germination test, under the same conditions, with results being expressed in centimeters.

Twenty-five replicates of 25 seeds were radiographed for each sarcotesta removal procedure, using a Faxiton digital equipment (model MX-20 DC12) coupled to a Core 2 Duo laptop $(3.16 \mathrm{GHz}, 2 \mathrm{~GB}$ memory, 160 GB hard drive). Radiation was used for 10 seconds, $32 \mathrm{kV}$ and a focal length of $30 \mathrm{~cm}$.

For the seed positioning, a double-sided tape was glued on transparent plastic sheets, with the seeds being organized in 5 rows of 5 seeds each. Then, the radiographed seeds were submitted to the germination test, in the same order of evaluation used for the X-ray test, in order to identify the seedling resulting from each seed.

From the X-ray images of the seeds, it was possible to determine the percentage of empty seeds, which did not show internal filling; poorlyformed seeds, which presented a different internal structure from the standard considered normal, such as dark spots or apparent deformations; flooded seeds, that showed an internal filling according to the standard considered normal; dormant or dead seeds, that appeared full in the X-ray images, but did not germinate until the end of the germination test; and damaged seeds, which presented some type of cracking.

The SVIS ${ }^{\circledR}$ software was used to determine the seed vigor from evaluating the seedling images (Marcos Filho et al. 2009), being obtained from four replicates of 25 seeds for each sarcotesta removal procedure. The seeds were placed to germinate in two rows located on the upper third of the paper towel surface, at $20-30{ }^{\circ} \mathrm{C}$, for 15 and 20 days. An HP Scanjet 200 scanner, inverted mounted inside a $60 \mathrm{~cm} \times 50 \mathrm{~cm} \times 12 \mathrm{~cm}$ aluminum housing, with a resolution of $100 \mathrm{dpi}$, was used for image capturing.

The normal, abnormal and non-germinated seedlings identified in each replicate (maximum 25) were transferred from the germination test to a sheet of black paperboard measuring $30 \mathrm{~cm}$ x $22 \mathrm{~cm}$ (corresponding to the size of the useful area reached by the scanner) and placed on the internal platform of a metal box, in order to obtain the images of the seedlings, which were saved after being scanned in a specific hard disk folder and then analyzed by the software, with the vigor index, growth index and uniformity index of the seeds being determined in each evaluation period.

The design was completely randomized, with 5 sarcotesta removal procedures distributed in four replicates of 200 seeds each. The data were submitted to analysis of variance by means of the F-Test and, when significant, the means of the treatments were compared by the Tukey test at $5 \%$ of probability, using the SAS $^{\circledR}$ software (Cody 2015).

\section{RESULTS AND DISCUSSION}

After being submitted to the sarcotesta removal procedures and dried in a laboratory environment, the seeds had their moisture content varying between $8.0 \%$ and $8.9 \%$ (Table 1). Because it is an 
intermediate classification, according to the sensitivity to desiccation, it was verified that the more dry and cool the seed, the lower the germinative power (Ellis et al. 1991). However, no sensible viability losses were observed, indicating that the conservation of the physiological potential may face variations in the water content and still withstand a more severe desiccation than many recalcitrant species (Marcos Filho 2015). In addition, the low moisture content found in the seeds may have provided a better visualization of the internal structures of the seeds (Carvalho et al. 2009).

In relation to the analyzed characteristics, only the seedling and root length showed a significant difference among the treatments, and it was possible to observe that the the blender + sieve method promoted a longer seedling length than that using only the sieve, but it did not differ from the other treatments.

The highest primary root growth was observed with the use of blender + sieve, in relation to the other tested procedures. Freitas et al. (2011), who evaluated methods of sarcotesta removing in germinating Jaracatia spinosa Aubli A. DC. seeds, which also belongs to the Caricaceae family, stated that the use of a blender is a simple, quick and easy way to handle the process, but also maintains the seed physiology quality.
In a study with papaya seeds, Cavalcante et al. (2014) concluded that the treatment using a sieve guaranteed a better seed performance. As in the present study, the seeds from all procedures were subjected to sieving, and the use of sieves together with other forms of squeezing removal, with the aid of a blender, may be more efficient than the removal with the sieve only, as it performs a more efficient sarcotesta removal and presents a high physical and physiological quality (Tables 1 and 2).

Analyzing the X-ray images allowed to evaluate the internal morphology of the papaya seeds (Figure 1), making it possible to classify them into four categories: empty, full, damaged and poorlyformed, and dormant or dead.

The X-ray images enabled to visualize the internal morphology of the papaya seeds, what is of great value, since the external visualization cannot differentiate the seeds in the mentioned categories, thus allowing discarding damaged seeds, or which are dormant and dead.

Although the number of poorly-formed seeds (Table 2) was low, it was possible to associate the effect of the internal morphology of the seeds with the seedling development from the poorly-formed

Table 1. Water content (WC), germination (G), first germination count (FGC), germination rate index (GRI), seedling length (SL), shoot length (SHL) and primary root length (PRL) of papaya seeds (Carica papaya) submitted to methods of sarcotesta removal.

\begin{tabular}{lccccccc}
\hline \multicolumn{1}{c}{ Methods } & WC $(\%)$ & G $(\%)$ & FGC & GRI & SL (cm) & SHL (cm) & PRL (cm) \\
\hline Fermentation + sieve & 8.2 & $74.5 \mathrm{a}$ & $11.37 \mathrm{a}$ & $1.92 \mathrm{a}$ & $18.60 \mathrm{ab}$ & $11.09 \mathrm{a}$ & $7.51 \mathrm{~b}$ \\
Sand + sieve & 8.8 & $63.0 \mathrm{a}$ & $10.38 \mathrm{a}$ & $1.76 \mathrm{a}$ & $18.36 \mathrm{ab}$ & $11.18 \mathrm{a}$ & $7.18 \mathrm{~b}$ \\
Sieve & 8.7 & $61.5 \mathrm{a}$ & $10.00 \mathrm{a}$ & $1.68 \mathrm{a}$ & $17.55 \mathrm{~b}$ & $10.34 \mathrm{a}$ & $7.20 \mathrm{~b}$ \\
Blender + sieve & 8.9 & $57.0 \mathrm{a}$ & $10.75 \mathrm{a}$ & $1.78 \mathrm{a}$ & $20.32 \mathrm{a}$ & $11.49 \mathrm{a}$ & $8.83 \mathrm{a}$ \\
\hline CV (\%) & & 15.08 & 22.75 & 13.05 & 5.42 & 5.61 & 6.75 \\
\hline MSD & & 20.30 & 5.10 & 0.49 & 2.30 & 1.30 & 1.10 \\
\hline F & & 2.38 & 0.24 & 0.70 & $5.27^{*}$ & 2.48 & $9.02^{*}$ \\
\hline
\end{tabular}

Means followed by the same letter in the column do not differ from each other by the Tukey test at $5 \%$ of probability. * Significant by the F-Test at $5 \%$ of probability.

Table 2. Percentage of empty (ES), poorly-formed (PFS), full (FS), dormant or dead (DMS) and damaged (DS) papaya (Carica papaya) seeds obtained from sarcotesta removal methods and analyzed by X-ray testing.

\begin{tabular}{lccccc}
\hline \multicolumn{1}{c}{ Methods } & ES & PFS & FS & DMS & DS \\
\hline Fermentation + sieve & $14 \mathrm{~b}$ & $1 \mathrm{a}$ & $78 \mathrm{a}$ & $7 \mathrm{~b}$ & $0 \mathrm{a}$ \\
Sand + sieve & $26 \mathrm{a}$ & $1 \mathrm{a}$ & $66 \mathrm{~b}$ & $7 \mathrm{~b}$ & $0 \mathrm{a}$ \\
Sieve & $21 \mathrm{ab}$ & $1 \mathrm{a}$ & $63 \mathrm{~b}$ & $15 \mathrm{a}$ & $0 \mathrm{a}$ \\
Blender + sieve & $24 \mathrm{a}$ & $2 \mathrm{a}$ & $62 \mathrm{~b}$ & $12 \mathrm{a}$ & $1 \mathrm{a}$ \\
\hline CV $(\%)$ & 8.93 & 11.68 & 4.63 & 11.60 & 8.93 \\
\hline MSD & 6.48 & 1.17 & 8.47 & 4.52 & 1.21 \\
\hline F & $2.99^{*}$ & $0.20^{*}$ & $3.32^{*}$ & $3.24 *$ & $3.00^{*}$ \\
\hline
\end{tabular}

Means followed by the same letter in the column do not differ from each other by the Tukey Test at $5 \%$ of probability. * Significant by the F-Test at $5 \%$ of probability. 
seeds. Figure 2 shows an example of a poorly-formed seed with its internal morphology (Figure 2A.1) and the abnormal seedling (Figure 2A.2) that developed from this seed.

According to Cícero \& Banzatto Júnior (2003), seeds with a damaged endosperm result in abnormal or dead seedlings, what was also described by Nunes et al. (2014) for pumpkin seeds (Cucurbita sp.). This may occur due to the lesser amount of nutrient reserve of the poorly-formed seed, what causes the seedling to have a lower performance, when compared to well-formed seeds.

The results for well-formed seeds corroborate those observed in the germination test. In a study conducted with castor bean seeds ( $R$. communis), Kobori et al. (2012) also observed that most of the seeds that formed normal seedlings were seeds that were classified as flooded, when evaluated by the X-ray test. Studying C. pachystachya seeds, Pupim et al. (2008) also observed these results. This may occur because the seeds being filled have all the structures necessary for twinning.

A non-germinated seed can also be observed in Figure 2, which internally was empty (Figure 2B.1), but, externally (Figure 2B.2), it was not differentiated from the other seeds. Identifying empty seeds is very useful to select only the seeds suitable for establishing the stand, thus improving the physiological quality of seed lots (Nunes et al. 2014). In addition, the radiographic analysis in the germination test allowed to identify seeds that could erroneously be considered dormant or dead.

From the images of seeds submitted to the $\mathrm{X}$-ray test, it was also possible to identify two seeds with mechanical damage caused by the blender procedure to remove the sarcotesta (Figure 3). Working with soybean seeds (Glycine max L.), Flor et al. (2004) also concluded that the X-ray technique was efficient in identifying internal mechanical damages in these seeds, showing that this technique can be tested and used for seeds of different species.

The results for vigor of papaya seeds submitted to the sarcotesta removal procedures through analyzing the seedling images processed in the SVIS ${ }^{\circledR}$ software, at 15 and 20 days after the germination test was installed, are present in Table 3.

There was no significant difference among the sarcotesta removal procedures, when their means
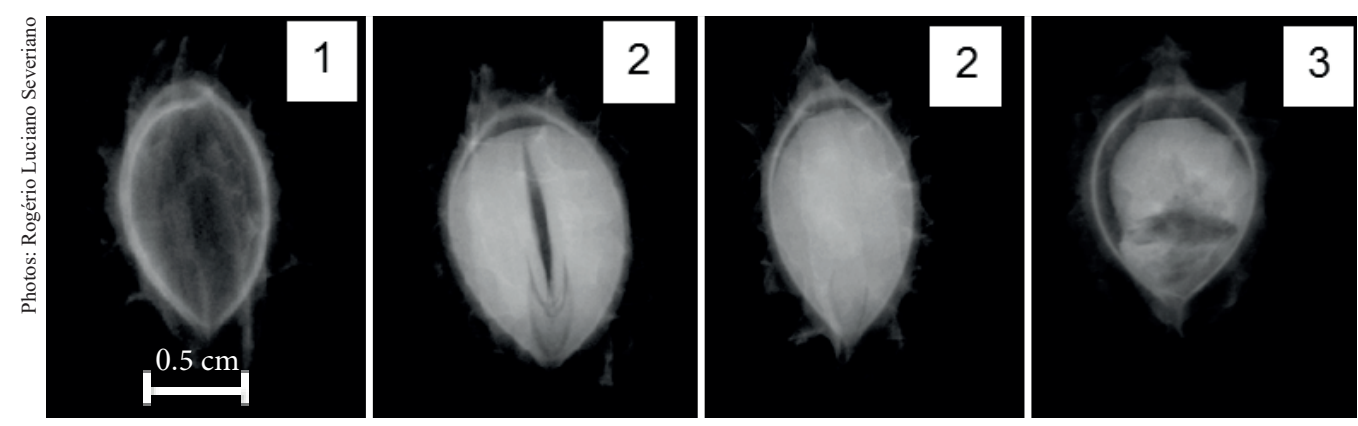

Figure 1. Radiographic images of papaya seeds (Carica papaya): empty (1), full (2) and poorly-formed (3).
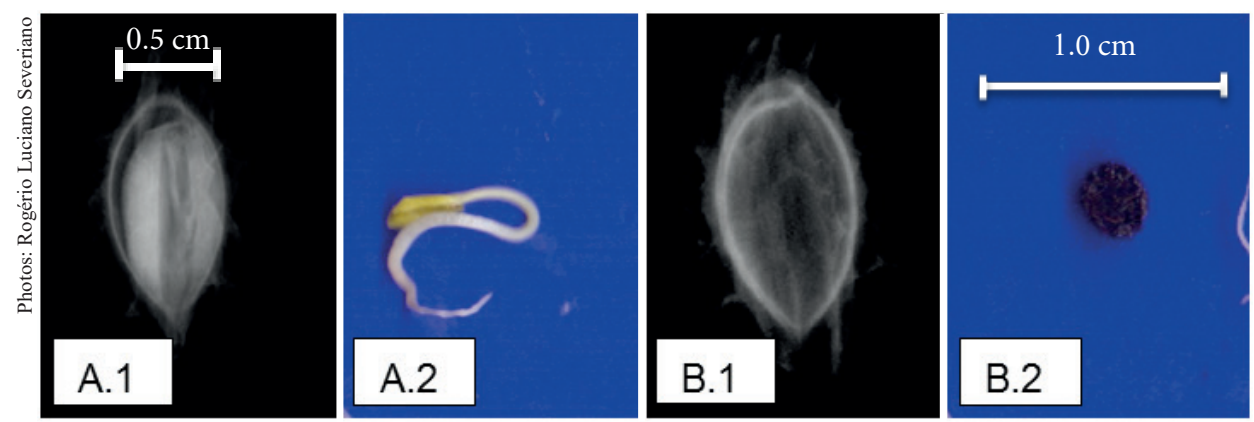

Figure 2. Radiographic image of a poorly-formed papaya (Carica papaya) seed (A.1) originating an abnormal seedling (A.2), and radiographic image of an empty seed (B.1) originating an ungerminated seed (B.2). 

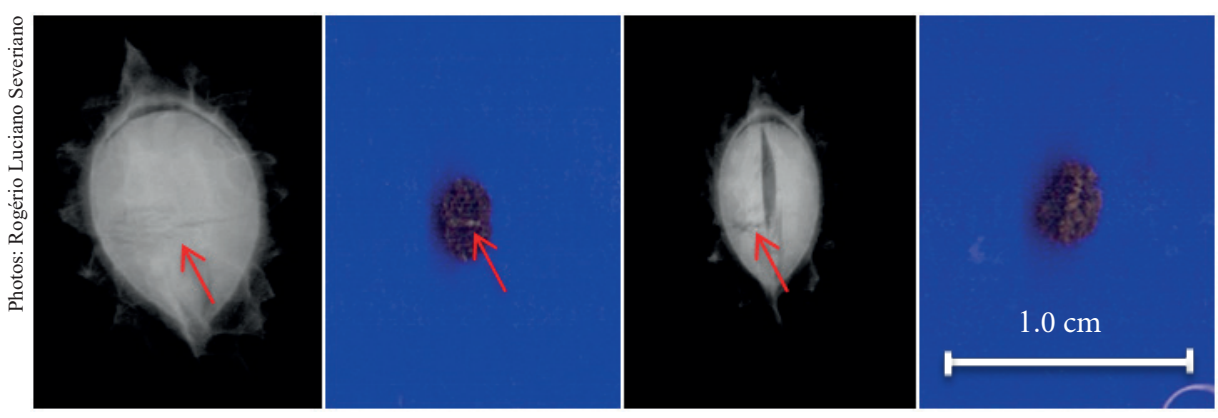

Figure 3. Radiographic images of papaya (Carica papaya) seeds with internal mechanical damage (red arrow), after being submitted to the procedure to remove the sarcotesta using the blender, causing dead seeds after the germination test.

Table 3. Vigor index (VI), growth index (GI) and uniformity index (UI) of papaya (Carica papaya) seeds submitted to methods of sarcotesta removal obtained at 15 and 20 days.

\begin{tabular}{lcccccc}
\hline \multirow{2}{*}{ Methods } & \multicolumn{4}{c}{15 days } & \multicolumn{2}{c}{20 days } \\
\cline { 2 - 6 } & VI & GI & UI & VI & GI & UI \\
\hline Fermentation + seive & $557.75 \mathrm{a}$ & $503.25 \mathrm{ab}$ & $687.25 \mathrm{a}$ & $737.50 \mathrm{a}$ & $722.00 \mathrm{a}$ & $774.50 \mathrm{a}$ \\
Sand + seive & $525.25 \mathrm{a}$ & $505.50 \mathrm{ab}$ & $572.75 \mathrm{~b}$ & $669.50 \mathrm{a}$ & $700.25 \mathrm{a}$ & $598.50 \mathrm{~b}$ \\
Seive & $519.50 \mathrm{a}$ & $476.00 \mathrm{~b}$ & $621.50 \mathrm{ab}$ & $743.75 \mathrm{a}$ & $788.25 \mathrm{a}$ & $641.25 \mathrm{~b}$ \\
Blender + seive & $650.25 \mathrm{a}$ & $677.75 \mathrm{a}$ & $587.75 \mathrm{a}$ & $770.25 \mathrm{a}$ & $813.75 \mathrm{a}$ & $670.50 \mathrm{ab}$ \\
\hline CV (\%) & 11.71 & 17.96 & 7.16 & 7.78 & 9.73 & 7.38 \\
\hline MSD & 138.55 & 200.80 & 92.80 & 119.30 & 154.50 & 104.10 \\
\hline F & 3.35 & $3.73^{*}$ & $5.30 *$ & 2.28 & 2.13 & $9.14 *$ \\
\hline Means followed by the same letter in the column do not differ from each other by the Tukey test at 5\% of probability. * Significant by the F-Test at 5\% of probability.
\end{tabular}

were compared by the vigor index in both evaluation periods (Table 3). The same result was observed by Marcos Filho et al. (2009), who concluded that the vigor index is more efficient when the variations between batches (treatments) are more accentuated, what shows that the vigor index calculated by the SVIS $^{\circledR}$ software does not detect differences in the physiological quality in batches that are similar to each other.

For the growth index, there were significant variations among the treatments only in the seedling evaluation carried out at 15 days, and the procedure that used the blender + sieve provided higher values than that which only used the sieve. This result corroborates that obtained in the physiological characterization of seeds for the seedling length variable (Table 1). This is explained by the fact that the growth index takes into account the relationship between the seedlings of the lot and the maximum size that the seedling can reach in a certain period of time (Kikuti \& Marcos Filho 2012).

Growth index data are dependent on seedling length results. For the growth index at 20 days, it was not possible to detect a difference among the treatments, possibly due to the later evaluation of the seedlings, because the longer the analysis period of the seedling images after the test installation, the greater is the stabilization period of the lot, thus reducing the vigor effects on its growth.

The uniformity index (Table 3 ) indicated that the procedures using the fermentation and the blender provided superior results to seeds that were submitted to the sarcotesta removal using sand at 15 days after installing the germination test. However, only the seeds submitted to fermentation produced seedlings at 20 days, which obtained a higher uniformity index value, if compared to the treatment using sand + sieve.

For Kikuti \& Marcos Filho (2012), evaluating the seed vigor using the SVIS $^{\circledR}$ software provided very similar results to the traditional tests on lettuce seeds (Lactuca sativa L.), for which the software was developed, in addition to a lower human interference. However, the results obtained in the present study indicate that, although it was not developed for papaya seeds, the SVIS ${ }^{\circledR}$ software also proved to be promising for evaluating the seed vigor of this species. 


\section{CONCLUSION}

Image analysis using the SVIS ${ }^{\circledR}$ software can identify a high physical and physiological quality in papaya seeds with the use of the blender + sieve method, which promotes a greater efficiency in the sarcotesta removal.

\section{REFERENCES}

BERBERT, P. A. et al. Qualidade fisiológica de semente de mamão em função da secagem e do armazenamento. Revista Brasileira de Sementes, v. 30, n. 1, p. 40-48, 2008.

BRASIL. Ministério da Agricultura e da Reforma Agrária. Regras para análise de sementes. Brasília, DF: SNDA/ DNDV/CLAV, 2009.

CARVALHO, M. L. M. et al. Teste de raios X na avaliação da qualidade de sementes de abóbora. Revista Brasileira de Sementes, v. 31, n. 2, p. 221-227, 2009.

CAVALCANTE, J. A. et al. Qualidade fisiológica de sementes de mamão submetidas a diferentes métodos de remoção da sarcotesta. Revista Verde, v. 9, n. 2, p. 285290, 2014.

CÍCERO, S. M.; BANZATTO JÚNIOR, H. L. Avaliação do relacionamento entre danos mecânicos e vigor, em sementes de milho, por meio da análise de imagens. Revista Brasileira de Sementes, v. 25, n. 1, p. 29-36, 2003.

CODY, R. An introduction to $S A S^{\circledR}$. Cary: SAS Institute, 2015.

DIAS, M. A. et al. Qualidade e compostos fenólicos em sementes de mamão alterados pela colheita e maturação dos frutos. Ciência Rural, v. 45, n. 4, p. 737-743, 2015.

ELLIS, R. H. et al. Effect of storage temperature and moisture on the germination os papaya seeds. Seed Science Research, v. 1, n. 1, p. 69-72, 1991.

FLOR, E. P. O. et al. Avaliação de danos mecânicos em sementes de soja por meio da análise de imagens. Revista Brasileira de Sementes, v. 26, n. 1, p. 68-76, 2004.

FREITAS, S. J. et al. Métodos de remoção da sarcotesta na germinação de sementes de jaracatiá. Revista Árvore, v. 35, n. 1, p. 91-96, 2011.

GOMES, K. B. P. et al. Avaliação da morfologia interna de sementes de Terminalia argentea (Combretaceae) pelo teste de raios X. Revista Ciência Agronômica, v. 45, n. 4, p. 752-759, 2014.

JESUS, V. A. M. Hipoclorito de sódio na remoção da sarcotesta e na qualidade fisiológica de sementes de mamão. 2014. 87 f. Dissertação (Mestrado em Fitotecnia) - Universidade Federal de Viçosa, Viçosa, 2014.

KIKUTI, A. L. P.; MARCOS FILHO, J. Testes de vigor em sementes de alface. Horticultura Brasileira, v. 30, n. 1, p. 44-50, 2012.
KOBORI, N. N.; CICERO, S. M.; MEDINA, P. F. Teste de raios-X na avaliação da qualidade de sementes de mamona. Revista Brasileira de Sementes, v. 34, n. 1, p. 125-133, 2012.

KRZYZANOWKI, F. C. et al. (Ed.). Vigor de sementes: conceitos e testes. Londrina: Abrates, 1999.

MAGUIRE, J. D. Speed of germination-aid in selection and evaluation for seedling emergence and vigor. Crop Science, v. 2, n. 1, p. 176-177, 1962.

MARCOS FILHO, J. et al. Métodos para avaliação do vigor de sementes de soja, incluindo a análise computadorizada de imagens. Revista Brasileira de Sementes, v. 31, n. 1, p. 102-112, 2009.

MARCOS FILHO, J. Fisiologia de sementes de plantas cultivadas. Londrina: Abrates, 2015.

MELO, A. P. C. et al. Maturação de frutos e tratamento pré-germinativo na produção de mudas de mamão. Revista de Ciências Agrárias, v. 38, n. 3, p. 330-337, 2015.

MELO, A. P. C.; SELEGUINI, A. Estádio de maturação de frutos e remoção física da sarcotesta na produção de mudas de mamão. Comunicata Scientiae, v. 4, n. 1, p. 20-25, 2013.

NUNES, R. T. C. et al. A análise de imagens na avaliação da qualidade fisiológica de sementes. Revista Verde, v. 9, n. 5, p. 84-90, 2014.

OLIVEIRA, L. M. et al. Avaliação da qualidade de sementes de Tabebuia serratifolia vahl nich. e $T$. Impetiginosa (Martius ex a. p. de Candolle) Standley (bignoniaceae) pelo teste de raios X. Revista Brasileira de Sementes, v. 26, n. 2, p. 138-143, 2004.

OLIVEIRA, L. M. et al. Utilização do teste de raios-X na avaliação da qualidade de sementes de canafístula (Peltophorum dubium (Sprengel) Taubert). Revista Brasileira de Sementes, v. 25, n. 1, p. 116-120, 2003.

PUPIM, T. L. et al. Adequação do teste de raios X para avaliação da qualidade de sementes de embaúba (Cecropia pachystachya Trec.). Revista Brasileira de Sementes, v. 30, n. 2, p. 28-32, 2008.

REIS, R. C. et al. Compostos bioativos e atividade antioxidante de variedades melhoradas de mamão. Ciência Rural, v. 45, n. 11, p. 2076-2081, 2015.

SAKO, Y. et al. A system for automated seed vigour assessment. Seed Science and Technology, v. 29, n. 3, p. 625-636, 2001.

SILVA, S. M. et al. Aryl removal methods and passion fruit seed positions: germination and emergence. Journal of Seed Science, v. 37, n. 2, p. 125-130, 2015.

TOKUHISA, D. et al. Tratamentos para superação da dormência em sementes de mamão. Revista Brasileira de Sementes, v. 29, n. 1, p. 131-139, 2007.

WENDT, L. C. et al. Avaliação do potencial fisiológico de sementes de soja por meio de imagens. Pesquisa Agropecuária Tropical, v. 44, n. 3, p. 280-286, 2014. 